\title{
PERKEMBANGAN KOGNITIF ANAK USIA 4-5 TAHUN DI TK ISLAM IBNU QOYYIM MEDAN SELAYANG
}

\author{
Fatma Gustina \\ Universitas Islam Negeri Sumatera Utara \\ Email: Fatmasiregar48@gmail.com. \\ Khadijah \\ Universitas Islam Negeri Sumatera Uara \\ Email: khadijah@uinsu.ac.id
}

\begin{abstract}
The purpose of this study was to determine the cognitive development of children aged 4-5 years in Islamic Kindergarten Ibnu Qoyyim Kec. Medan at a glance, Setia Budi. This research method is qualitative, which uses observation, interview, and documentation instruments. Analysis of the data used is data collection, data reduction, data display and draw conclusions. Research findings show (1) children's cognitive development is developed through several methods, such as playing, playing arithmetic, learning while playing with gometry, conducting science experiments and various methods that are creatively packaged by the teacher. (2) the cognitive development of children in Ibnu Qoyyim's kindergarten develops, seen from the child's observation sheet, 7 out of 8 cognitive development with satisfactory value. (3) teacher creativity and teacher methods are very important influences in the development of cognitive programs in Ibn Qoyyim Kindergarten. The obstacle in children's cognitive development is that children rarely attend school.
\end{abstract}

Keywords : Development, cognitive, methods, play

\section{Abstrak}

Tujuan penelitian ini adalah untuk mengetahui perkembangan kognitif anak usia 4-5 tahu di TK Islam Ibnu Qoyyim Kec. Medan selayang, Setia Budi. Metode penelitain ini adalah kualitatif, yang menggunakan instrumen observasi, wawancara, dan dokumentasi. Analisis data yang digunakan yaitu pengumpulan data, reduksi data, display data dan menarik kesimpulan. Emeuan penelitian menujukakkan (1) perkembangan kognitif anak dikembangkan melalui beberapa metode, misalnya bermain, bermain aritmatika, belajar 
sambil bermain dengan gometri, melakukan percobaan sains dan berbagai metode yang dikemas secara kreatif oleh guru. (2) perkembangan kognitif anak di TK ibnu Qoyyim berkembang, terlihat dari lembar observasi anak, 7 dari 8 berkembang kognitifnya dengan nilai yang memuaskan. (3) kreativitas guru dan metode guru sangat berpengaruh penting dalam perkembangan kogiti ank di TK Ibnu Qoyyim. Hambatan dalam pengembangan kognitif anak ialah,apabila anak jarang hadir kesekolah.

Kata Kunci Pengembangan,Kognitif, metode, bermain

\section{PENDAHULUAN}

Anak usia dini adalah anak yang baru dilahirkan sampai usia 6 tahun. Usia ini merupakan usia yang menentukan dalam pembentukan karakter dan kepribadian anak. Berdasarkan aspek pedagogis, masa usia dini merupakan masa peletak dasar atau pondasi awal bagi pertumbuhan dan perkembangan selanjutnya. Diyakini oleh sebagian besar pakar bahwa masa kanak-kanak yag bahagia merupakan dasar bagi keberhasilan masa mendatang dan sebaliknya. Pada undang undang permendiknas tahun 2009 No. 58 yaitu tentang kurikulum TK islam yang meliputi beberapa aspek perkembangan yaitu, aspek perkembangan sosial emosional, aspek perkembangan moral dan agama, dan kemandirian. Pengembangan kemampuan dasar yaitu, kemampuan bahasa, fisik, dan kognitif. Kognitif bertujuan untuk mengembangkan cara berpikir anak, agar anak bisa mengatur cara berfikitnya, seperti anak dapat menemukan bernagai macam cara untuk memecahkan masalah yang dihadapinya saat belajar.

Pengembangan kognitif yaitu kebisaan seorang anak untuk lebih tahu tentang sesuatu, yang artinya mampu mengetahui sifat benda, mengelompokkan benda dan mempunyai pengertian serta gambaran tentang susuatu secara jelas. Perkembangan kognitif yaitu berada pada kemampuan seorang anak untuk mengartikan dan memahami sesuatu.

Perkembangan kognitif anak usia dini berkembang secara bertahap. Seorang anak tidak dapat menerima pengetahuan secara langsung dan tidak bisa langung menggunakan pengetahuan tersebut, tetapi pengetahuan akan di dapat secara bertahap dengan cara belajar secara aktif di lingkungan sekolah. Dalam perkembangan kognitif di sekolah, guru adalah orang yang betanggung jawab dalam melaksanakan interaksi edukatif dan perkembangan 
kognitif anak, guru perlu memiliki pemahaman yang sangat mendalam tentang perkembangan kognitif anak usia dini.

Orang tua juga memiliki peran yang sangat penting dalam perkembangan kognitif anak karena perkembangan dan pertumbuhan anak terlebih dahulu dimulai dari lingkuangan keluarga. Namun sebagian guru dan orang tua belum terlalu memahami tentang perkembangan kognitif, karakteristik perkembangan kognitif, dan masalah lain yang berhubungan dengan perkembangan kognitif anak usia dini. Menurut Tina bermain adalah satu kegiatan yang dilakukan untuk dapat menimbulkan kesenangan dan tidak mengharapkan hasil akhir. Ermain juga dapat memberikan anak sesuatu hal atau pengalaman yang tidak didapatkan seorang anak melalui materi pelajaran yang dilakukan.

Tina Dahlan berpendapat bahwa bermain dapat mengembangkan beberapa aspek perkembangan anak usia dini, yaitu aspek kognitif, fisik motorik, bahasa, emosi, moral dan sosial. Selain itu bermain dapat membantu anak lebih mudah memahami suatu materi pelajaran. Agar bermain dapat mengembangan beberapa aspek perkembangan tersebut, guru diharapkan dapat merancang sebuah permainan yang dapat mengembangkan aspek perkembangan tersebut. Bermain pada anak bukan hanya sekedar bermain tetapi bermain sambil belajar. Beberapa contoh permainan yang dapat mengembangkan kognitif yaitu bermain geometri, melakukan percobaan sains, pengembangan Audytori, permainan tebak gambar, dan permainan jari aritmatika.

Jen Piaget berpendapat bahwa tahap perkembangan kognitif seorang anak akan terus berkembang sampai menyamai Proses berfikirnya orang dewasa. Suatu proses yang terperinci tentang perkembangan intelektual anak. Pada saat bermain anak tidak belajar sesuatu yang baru, tetapi sedang mengonsilidasikan dan memperaktekkan keterampilan yang baru yang mereka temukan. Dalam permainan anak tidak belajar sesuatu yang baru, tetapi sedang memperaktekkan sesuatu yang sebelumnya ia pelajari.

Bermain adalah latihan untuk mengembangkan pengetahuan dan keterampilan kognitif yang baru sehinga dapat berkembang secara teratur da baik. Menurut khadijah bermain merupakan wahana bagi anak untuk melakukan kegiatan bermacam-macam eksperimen tentang bermacam konsep yang suddah dikenal dan yang belum dikenal. 
Aktivitas bermain dilakukan anak dengan cara mendengar dan mengamati. Aktivitas mendengar dilakukan anak dengan cara menyimak bunyi, nada, suara, kemudian melihatpersamaan bunyi, sura, dan nada. Anak dapat memecahkan masalah sederhana berdasarkan pengetahuannya tentang bunyi tersebut. Aktivitas mengamati dilakukan anak dengan melihat warna, bentuk, dan ukuran. Anak dapat melihat persamaan dan perbedaan bentuk, warna, dan ukuran. Kemudian anak menyelesaikan masalah berdasarkan pengetahuannya tentang bentu, warna, dan ukuran tersebut.

Ada berbagai macam jenis permainan yang bisa mengembangkan kognitif dan dapat disuguhkan pada anak. Berbicara tentang sains tak luput dari membicarakan seputar eksperimen langsung. Oleh karena itu, bermain sains ini berhubungan dengan aktivitas kognitif karena saat melakukan percobaan secara tidak lansung anak telah melakukan pengamatan dan penyelidikan. Contohnya seperti sains tentang pencampuran warna. Dalam permainan ini aktivitas kognitif anak terlibat, dilihat dari pemecahan masalah sederhana, mulai dari yang mudah ke yang sulit. Menghitung botol minuman yang ada di atas meja, menghitung tas teman dalam kelas, menghitung crayon dan pensil milik sendiri. Menyocokkan bilangan dengan lambang bilangan 1-10, menyocokkan kartu angka dengan jumlah botol minum yang ada di atas meja.

TK Islam Ibnu Qoyyim adalah sekolah taman kanak kanak yang berbasis Islam, yang menekankan pembelajaran sambil bermaian dan mengembangkan beberapa aspek perkembangan anak. Pembalajaran sambil bermain, menutut guru menciptakan suatu pembalajaran yang menarik dan tidak membosankan. Jika dalam mengmbangkan kognitf, hanya dengan cara memberikan materi dan monoton maka anak akan mera bosan dan tidak tertarik dalam belajar. Pada TK Islam tersebut, anak anak banyak melakukan kegiatan yang mengembangakan kognitif tetapi sambil bermain, guru pada TK tersebut menggunakan metode bermain sebagai salah sau cara untuk mengembangkan kognitif anak anak. Di TK tersebut anak anak sering melakukan sain percobaan, permainan geometri, jari aritmatika, Audytori dan geomrti untuk mengembangan kognitif.

Di TK tersebut, guru merancang pembelajaran yang dapat mengembangkan kognitif anak dengan cara bermain yang tentu saja menyenangkan. Dalam pembelajaran tersebut, 
kognitif juga tidak dikembangkan dengan cara monoton, guru selalu mempunyai kegiatan kegiatan yang berbeda setiap hari dan menyenangkan anak. Contoh kegiatan yang dilakukan gru, pada saat melakukan penelitian adalah membedakan sifat benda, dimana ada beberapa sifat benda yang harus diketahui anak, contoh nya seperti, kasar, halus,tebal, tipis, panas, dingin, dan lain halnya. Dalam pembelajar pegembangan kognitif ini, anak anak di berikan benda benda yang menarik agar anak mengetahui sifat benda, dan perkembangan kognitifnya berkembang.

Kegiatan -kegiatan yang dilakukan anak di TK Ibnu Qoyyim adalah kegiatan belajar sambil bermain, yang bertujuan untuk mengembangakan kognitif anak. Karena pihak sekolah dan guru menyadari bahwa aspek perkembangan anak haruslah dikembangkan dengan baik, terutama aspek perkembangan kognitif karena penting untuk kelanjutan masa depan akan tersebut. Dengan demikan, penelitian ini dilakukan untuk mengamati bagaiman perekambangan kognitif di sekolah TK Islam Ibnu Qoyyim. Dengan metode bermain dan dengan pelajaran yang berbasis bermain, serta pelajaran yang menarik dan tidak membosankan apakah perkembangan kgonotif disekolah tersebut berkembang dengan baik dan susuai dengan strandar perkembangan kognitif anak usai 4-5 tahun.

Anak usia dini adalah anak yang berusia 0-6 tahun yang pada masa ini segala perkembagan terjadi di usia tersebut, dan pada usia ini anak menyerap informasi sebanyak banyaknya. Dan pada masa ini adalah kesempatan guru dan orang tua untuk mengembangkan berbagai aspek perkembangan anak terutama kognitif anak agar berkembang dengan baik.

\section{METODOLOGI}

Jenis penelitian yang dilakukan adalah penelitian kualitatif. Penelitian ini dilakukan untuk mendeskripsikan tentang semua hal yang berkaitan dengan perkembangan kognitif di TK Islam Ibnu Qoyyim anak usia 4-5 tahun KEC. Medan Selayang Setia Budi. Penelitian ini dilaksanakan pada tanggal 7 Oktober 2019 sampai dengan 27 November 2019. Sumber data pada penelitian ini adalah sumber data primer yaitu sumber dapat yang diambil secara langsung, yakni mengamati langsung kegitan anak, mewawancarai guru dan kepala sekolah TK Ibnu Qoyyim. Penelitian ini juga menggunakan data sekunder peneliti mengambil 
tentang informasi sekolah seperti profil sekolah, sarana prasana sekolah, catatan catan kognitif anak, dan segala yang berkaitan dengan kognitif anak di Tk Islam Ibnu Qoyyim. Instrumen penelitian ini adalah, observasi, wawancara dan dokumentasi. Teknik analisis data yang dilakukan oleh peneliti yaitu dengan tahap pengumpulan data, reduksi data, display data serta menarik kesimpulan.

\section{HASIL DAN PEMBAHASAN}

Pengembangan kognitif di TK Islam Ibnu Qoyyim dikembabangkan dengan cara bermain sambil belajar. Kognitif anak dikembangkan dengan cara belajran sambil bermain oleh guru yang bertugas mengembangkan kognitif tersebut. Pada sekolah tersubut, guru tidak hanya mengembangkan kognitif dengan metode bermain tetapi dengan beberapa metode yaitu metode Bermain.

Bermain adalah latihan untuk menghubungkan macam-macam pengetahuan dan keterampilan kognitif yang baru disadari sehingga bisa berfungsi secara teratur. Menurut khadijah bermain merupakan wahana bagi anak untuk melakukan kegiatan bermacammacam eksperimen tentang bermacam konsep yang suddah dikenal dan yang belum dikenal. Aktivitas bermain dilakukan anak dengan cara mendengar dan mengamati. Aktivitas mendengar dilakukan anak dengan cara menyimak bunyi, nada, suara, kemudian melihatpersamaan bunyi, sura, dan nada. Anak dapat memecahkan masalah sederhana berdasarkan pengetahuannya tentang bunyi tersebut. Aktivitas mengamati dilakukan anak dengan melihat warna, bentuk, dan ukuran. Anak dapat melihat persamaan dan perbedaan bentuk, warna, dan ukuran. Kemudian anak menyelesaikan masalah berdasarkan pengetahuannya tentang bentu, warna, dan ukuran tersebut.

Ada berbagai macam jenis permainan yang bisa mengembangkan kognitif dan dapat disuguhkan pada anak usia dini. Bermain Sains yaiut Berbicara tentang sains tak luput dari membicarakan seputar eksperimen langsung. Oleh karena itu, bermain sains ini berhubungan dengan aktivitas kognitif karena saat melakukan percobaan secara tidak lansung anak telah melakukan pengamatan dan penyelidikan. Contohnya seperti sains tentang pencampuran warna. Saat proses pencampuran warna dasar, anak fokus dan berfikir kenapa warna hijau dicampur dengan kuning menjadi orange, Alat dan bahan yang perlu 
disediakan Air, Pewarna makanan cair (merah, hiajau, dan biru), Cup plastik bening. Cara bermain, Anak duduk melingkar, beri satu anak 2 cup bening yang sudah diisi air. Lalu suruh anak meneteskan pewarna makanan ke dalam cup yang pertama satu warna saja. Lalu biarkan anak bertanya kenapa airnya berubaha menjadi berwarna. Biarkan anak berpikir, sebeb disitulah aktifitas kognitifnya sedang berproses. Setelah itu minta lah anak untuk meneteskan lagi pewarna makanan ke dalam cup yang sudah berwarna itu, lalu perhatikan reaksi anak setelah melihat perubahan warnanya. Terakhir, minta anak melakuknnya sendiri di cup 2 yang berisi air tadi tanpa diajari guru. Biarkan anak memilih warna yang ia sukai.

Dalam menjawab rumusan masalah dan pertanyaan-pertanyaan penelitian, hasil penelitian harus disimpulkan secara eksplisit. Penafsiran terhadap temuan dilakukan dengan menggunakan logika dan teori-teori yang ada. Temuan berupa kenyataan di lapangan diintegrasikan/dikaitkan dengan hasil-hasil penelitian sebelumnya atau dengan teori yang sudah ada. Untuk keperluan ini harus ada rujukan. Dalam memunculkan teori-teori baru, teori-teori lama bisa dikonfirmasi atau ditolak, sebagian mungkin perlu memodifikasi teori dari teori lama.

Bermain matematika, Dalam permainan ini aktivitas kognitif anak terlibat, dilihat dari pemecahan masalah sederhana, mulai dari yang mudah ke yang sulit. Menghitung botol minuman yang ada di atas meja, menghitung tas teman dalam kelas, menghitung crayon dan pensil milik sendiri. Menyocokkan bilangan dengan lambang bilangan 1-10, menyocokkan kartu angka dengan jumlah botol minum yang ada di atas meja. Metode bercerita ,Bercerita sama artinya dengan mendngeng. Dalam pengembangn kognitif anak bercerita atau mendongeng merupakan ssalah satu metode yang tepat untuk digunakan karena salah ssatu tujuan dari metde bercerita menstimulasi daya imajinasi dan kreativitas anak, dan memperkuat daya ingat anak, lalu membuka alam pemikiran anak menjadi cerdas dan lebih kritis.

Metode dongeng membuat anak berani menantang untuk menanggapi cerita, menggetarkan pearasaaan dan hati nuraninya. Bercerita dapat dilakukan guru dengan menggunakan media seperti boneka tangan (puppet), buku bergambar, dan atribut lainnya yang menarik untuk anak. Lalu guru memilih topik cerita yang memang dapat dinalar anak 
atau cerita sederhana yang mudah difahami dan anak dapat menceritakan kembai kepada teman sebaya maupun anggota keluarganya. Cerita yang menarikuntuk anakialah cerita fabel(tokoh binatang) atau cerita yang langsung melibatkan diri anak, namun fabel tetap lebih disukai karna di masa kanak-kanak imajinasi sangt tinggi, anak menganggap binatang itu dapat berbicara seperti manusia. Seperti cerita kelinci yang sombong dan kura-kura yang sukamemaafkan misalnya.

Di sebuah hutan lindung, hiduplah seekor kelinci putih yang sangat pintar, kelinci itu senang sekali melompat dan berlari, lalu pada suatu pagia ia berjalan-jalan melewati pinggir sugai, kelinci bertemu dengan kura-kura yang jaannya lambat. Lalu kelici mengejek dan menantang kura-kura untuk berlomba lari, awalnya kura-kura kebertan. Tapi karena ke;linci tetap mendesak juga akhirnya kura-kura menngangguk setuju. Keesokaan harinya perlombaan pun di mulai, kelinci sudah hadir di langan, kura-kura belum muncul juga. Kelinci hampir marah, 10 menit kemudian kura-kura pun tiba di lapangan lomba. Wasit meniup peluit tanda perlombaan akan di mulai, kelinci dengan sigapnya berlari dengan lompatannya yang cepat, di pertengahan jalan kelici berhenti, ia tidak melita kura-kura, kelinci berpikir kura kura masih jauh dan kelincipun tertidurdi bawah pohon mangga. Dengan perlahan, kura-kur melewati kelinci itu, dan tidak lama kemudian kura-kura pun sampai ke garis finish. Wasit menentukan bahwa kura-kura lah yang menjadi pemenang dalam perlombaan itu.kelinci merasa malu karena ia sering mengejek kura-kura dan memandang sepele. Kelinci malu dan meminta maaf kepada kura-kura dan kurakura yang baik hati it pun mmaafkan kelinci dan mereka pun berpelukan lalu menjadi teman baik.

Cerita di atas merupakan salah ssatu contoh cerita sederhana yang mudah dipahami anak. Selain dapat mengembangkan kognitif, bercerita juga dapat menanamkan nilaikarakter baik pada diri anak.Tergantung cerita yang dipilih. Cerita kelinci yang yang sombong dan kura-kura yang suka menolong cocok disuguhkan pada anak usia dini. Sebab pikiran anak akan terbuka, bagaimana kura-kura yang jalannya lambat itu berlomba lari dengan kelinci yang jalannya melompat dengan cepat. Tujuan metode bercerita ini tak lepas dari mengembaangkan kemampuan berbicara dan memperbaanyak perbendaharan kata anak, 
mengenalkan bentuk emosi dan ekspresi kepada anak .seperti marah, sedih, senang, kesal, dan merasa kritis.

Metode tanya jawab Menurut Pandi dalam Khadijah, metode tanya jawab adalah tinjauan pelajaang yang telah berlalu agar anak dapat kembali memusatkan perhatiaannya tentang sejumlah kemajuan yang telah dicapai hingga datimuluspat melanjutkan pelajaran baru untuk menstimulus siswa. metoda tanya jawab dipandang dapat mengembangkan kemampuan kognitif anak karena metode ini merangsang perhatian agar anak fokus pada pelajaran yang sedang berlangsung. Metode tanya jawab ini juga dapat mengarahkan proses berpikir anak atau siswa.

Metode karyawissata, Metode karyawisata menurut Moeslichaton dalam Khadijah, anak usia dini menggunakan semua panca indranya untuk mengamati alam sekitarnya secara langsung saat kegiatan karyawisata. Metode karyawisata dapat mengembangkan pengetahuan dan memperluas wawasan. Catherin Landertdalam Khadijah mengungkapkanbahwa proses belajar anak usia dini lebih ditekankan pada aktif berbuat dari mendengarkan, dalam arti lain pembelajaran berpusat pada anak, bukan pada guru, maka saat proses pembelajaran berlangsung beri bahan yang banyak agar aktivitas yang dilakukan anak juga banyak sehingga anak akan belajar sendiri dari pengalamannya. Metode ini bagus diterapkan untuk mengembangkan kognitif anak usia dini.

Berdasarkan observasi yang dilakukan oleh peneliti, peneliti melihat guru menerapkan permainan yang menarik untuk mengembangkan kognitif anak di Tk Islam ibnu Qoyyim teresebut. Dengan menggunakan beberapa teori yang dan di impelemntasikan kepada pembelajaran tersebut. Kognitif anak dikembangakan dengan beberapa permainan dan metode. Perkembangan kognitif anak disekolah tersebut, rata rata sudah berkembang, seperti yang sudah dilampirkan berikut ini,

1. Mendengaran bunyi

Setiap pembelajaran disekolah, Ibnu Qoyyim tersebut dimulai dengan anak mendengarkan suara lonceng, itu dilakukan dari anak masuk sekolah sehingga dia mengenal bahwa itu adalah bel yang menandakan masuk atau istirahat lonceng yang menandakan untuk pulang sekolah. Dengan langkah tersubut tanpa disadari anak jadi mengenal bunyi, 
sehingga ketika ia mendengar bunyi tersebut dia bisa mengatakan ini bunyi lonceng untuk masuk kelas, ini bunyi lonceng untuk istirahat dan ini bunyi lonceng menandakan bahwa waktu belajar sudah habus dan di persilahkan untuk pulang kerumah. Anak sudah dapat menjelaskan,bunyi yang di dengarnya, seperti pada saat anak mendengar bunyi suara lonceng, bunyi suar adan lain halnya.

2. Mendengarkan Nyanyian

TK tersubut sebelum memulai pelajaran, selalu memutarkan lagu lagu yang sesuai dengan umur anak, misalnya seperti lagu "Anak Nabi", "Zummi Zummi dan lain sebagainya, dari anak mendengarkan lagu tersebut hampir setiap hari anak dapat menebak lagu tersebut dan hafal dengan lirik lagu tersebut, dengan begitu saat mendengarlagu anak ikut bernyanyi dan hafal dengan lirik tersebut, tidak habya itu, anak disekilah itu dapat mendeskripsikan dengan jelas apa makna lagu yang ia nyanyikan, karena konsep guru adalah menghafalkan nyanyian dan memutarkannya secara ber uluang ulang selama 2 minggu pembelajaran, walaupun dengan sub tema subtema yang berbeda beda. Guru disini sudah lama mendengarkan nyanyian nyanyian yang sesuai dengan umur anak, karna menurut guru dengan nyanyian lebih mudah dalam menyampaikan pesan atau meyampaikan ilmu dan informasi, karena saat memyanyi anak tidak merasa dipaksa dan anak merasa senang melakukannya.

3. Mengikuti perintah

Di TK ibnu Qoyyim anak dibiasakan untuk mendengar perintah tapi perintah yang dimaksud adalah perintah yang ringan yang dilakukan untuk kebutuhan anak. setelah mendengarkan perintah tersebut anak langsung melakukan atau mengerjakan yang di perintahkan oleh guru. Pada saat guru mememrintahakan anak, guru dengan lemah lembut selalu menggunakan kata "Tolong nak" dan selalu mengucapkan " Terimakasih sayang" untuk hal yang sudah dilakukan anak. Ada juga guru yang memeluk dan mencium anak, jika perintah yang diterima anak dilakukan dengan baik dan sempurna, seperti halnya pada saat guru menyuruh anak merapikan tasnya ke tempat yang sudah disediakan, guru mengatakan “ Tolong ibu untuk merapikan tas kakak ke rak tas nak" dan setelah anak merapaikannya, guru mengatakan " terima kasih banyak sayang sudah menolong ibu untuk merapikan tas kakak". 
Dan yang dilakukan guru saat menyuruh anak untuk mengambil minumannya sendiri dan makan dengan habis dan lahap, guru selalu mengatakan "terimaksih sayang tidak membuang buang makanan" lalu guru tersebut mencim dan memeluk anak tersebut.

4. Mendengarkan cerita

Di TK islam Ibnu Qoyyim selalu bercerita pada hari rabu dan hari jum at,jum at di khususkan dengan cerita Nabi, tetapi pada hari rabu, gu menceritakan kisah kisah yang dapat memeotivasi anak untuk tidak smbong dan berperilaku baik, seperti pada saat meneliti, tepat pada hari rabu guru menceritakan sikah "Kura - Kura dan kelinci" kemudian, dengan seksama dan dengan berbagai macam reaksi dan eksperi yang dilakukan guru, untuk menggambarkan berbagai tokoh dalam cerita, anak jadi mendengarkan degan konsentrasi penuh, dan anak mendengarkannya tanpa ribut, dan konsentrasi untuk memaknai cerita tersebut, seperti saat saat menegangkan, anak juga terbawa dalam cerita dan ikut tegang mendengarkan cerita tersebut. Setelah guru bercerita, anak menanggapi damulai memahami cerita tersebut, keesokan harinya, beberapa anak berkumpul dan bercerita kepada anak yang tidak hadi pada hari rabu tersebut, mereka bercerita tentang "kura- kura dan kelinci" yang di ceritakan guru pada hari rabu. Anak anak tersebut menceritakannya dengan pemahaman mereka tetapi dengan makna yang sama dengan yang di ceritakan guru. Jadi anak memahami cerita yang sudah di ceritakan guru tersebut.

5. Membandingkan ukuran benda

Sebelum memumulai pelajaran, guru selalu memberikan maianan balok kepada anak, dan memberika puzzel, serta lego, yang menari adalah anak yang dapat menyusun lego dan balok sesuai yang sudah di contohkan guru pada hari itu, diberikan reward yaitu bintang di tambah di papan bintang, anaka anak semangat membedakan panjang pendek, besar kecil serta tinggi rendahnya suatu benda,semua anak di kelas itu sudah bisa melakukan dan membedakan ukuran benda tersebut, tetapi ada anak anak yang melakukan nya dengan cepat dan tanpa salah, dan dikelas tersebut tidak ada anak yang tidak bisa melakukannya dan tanpa bantuan guru. Guru mengatakan bahwa dari mereka masuk pertama kalli di kelas, mereka diajarkan untuk membandingkan ukuran benda, sehingga sekarang hanya 
melanjutkan kebiasaan dan untuk tahap yang lebih konkrit dalam membandingkan ukuran benda tersebut.

6. Membedakan sifat benda

Dalam membedakan sifat benda, guru melakukan percobaan sains sederhana, contohnya guru menyediakan beberapa air yang dibeikan pewarna makanan, dan anak dapat melihat perubahan yang terjadi apabila dilakukan pencampuran warna. Anak juga dibiasakan melihat gambar yangwarnanya sesuai dengan objek, seperti daun yang warnanya ada hijau, coklat bila layu, anak anak jadi mengerti bahwa dauin itu ada yang berwarna hijau dan jika layu daun akan berubah menjadi coklat. Semua anak menegerti tentang membedakan sifat benda dan bia mengettahui bahwa objek yang dilihatnya bisa ia deskripsikan warnanya. Kumudian anak bisa membedakana kasar dan lembut, seperti saat guru menutup mata anak, dan menyuruh menebak apa yang sedang dia sentuh, kemudian dia mendeskrisikan bahwa tepung itu halus, dan pasir itu kasar, hampir semua anak dapat mendeskripsikan hal tersebut. Kemudian pada saat anak membedakan tebal dan tipis, pada saat saya memberikan dua buku dan menanyakan yang mana yang paling tebal anak menjawab dengan benar, guru megakatakan mereka melakukan perbandigan tersebut ketika anak sedang membawa buku guru menanyakan, "lebih tebal Iqro atau buku tulis ini" dan anak menjawab dengan benar karena selalu di biasakan oleh guru.

Anak dapat membedakan panas dan digin, seperti selalu dijelaskan oleh guru bahwa api itu panas, jika apinya semakin besar maka anak anak tidak boleh mendekat, karna dapat membahayakan anak anak. Kemuadia dingib, kulkas itu dingin, jika di letakkan air di dalam kulkas maka airnya akan membeku dan dingin, maka mereka melakukan praktek, guru menyediakan dua gelas, satu berisi air hangat da satunya berisi air dengi, kemudian anak di suruh menulis, gelas mana yang berisi panas atau dingin. Setelah lembaran mereka di kumpulkan semua, semua anak menjawab dengan benar. Anak anak tersebut dapat membedakan panas adan dingin.

7. Mewarnai sederhana

Anak di TK Ibnu Qoyyim dibiasakan untuk mewarnai, tetapi dengan berbagai ojek dan sketsa sketsa yang berbeda beda, pada saat peneliti melakukan penelitian,guru 
memberikan anak sketsa gambar pohon, kemudian hampis semua anak menggambar daun pohon tersebut warna hijau, dan batang pohon tersebut berwarna cokla, mereka sudah mengerti bahwa setiap objek mempunyai ciri khas warna masing masing. Hampis semua anak mewarnai dengan baik.

8. Menyusun Dan Menggabungkan

Pada sekolah tersebut terdapat beberapa Puzzle sederhana yang terbentuk dari gambar gamabar, dan anak anak ika kegiatannya sudah selesai dilakukan bisa melakukan kegiatan dalam menggabungkan gambar tersebut, rata rata dengan permainan menggabungkan puzzle gambar anak anak bisa melakukannya secara baik dan ada beberapa anak yang melakukan kegiatan tersebut dengan sangat cepat. Kemudian di lembar kerja anak, guru membuat beberapa gambar dan anak disur membuat pola mengikuti gambar tersebut, dilihat dari hasil pekerjaan anak, anak dapat melaukan nya dengan baik dan bagus. Dan pada saat guru memberikan balok kepada anak, mereka dapat membangun sebuat menara yang bagus dan baik, walaupun masih tahap menara yang sederhana.

9. Mengurutkan bilangan

Guru memberikan beberapa benda, ada benda yang ringan,berat, tinggi, rendah, panjang dan pendek, anak di tugaskan untuk mengurutkan benda tersebut dari ringan ke berat, panjang ke pendek, lalu tinngi kerendah, hal itu dilakukan sekali dalam seminggu, rata rata hasil pengamatan peneliti, anak dapat mengurutkan bilgan tersebut.

10. Meniru

Guru menggambar beberapa geometri, seperti segitiga, dan gambar yang disesuaikan dengan sebuah objek. Anak anak di suruh mengikuti pola yang di gambar oleh guru, anak anak tidak mengalami hambatan dalammeniru sebuah gambar atau sebuah objek, mereka melakukannya dengan cekatan dan baik. Beberapa anak menyelesaikan ugas tersebut dengan cepat dan benar.

\section{SIMPULAN}

Berdasarkan penelitian yang dilakukan, Perkembangan Kognitif anak kelas A usia 45 tahun sudah berkembang baik. Mereka mempunyai fasilitas untuk mengembangkan 
Kognitif anak, dan hampir semua anak perkembangan Kognitif baik, karna di stimulus dengan baik. Dari penelitian ini, penulis menyimpulkan perkembangan kognitif di sekolah tersebut sudah berkembangan dengan baik dan dengan penelitian yang menunjukkan anak sudah berkembang Kognitifnya. Kendala dalam pengembangan Kognitif ini adalah, ketika anak pemalu dan anak yang jarang masuk sekolah, anak tersebut akan mengalami keterhambatan perkembangan Kognitifnya karna merasa kurang percaya diri dengan apa yang dilakukannya. Peneliti mengambil sampel sebayak 8 orang dari kelas A yang usia 4-5 tahun, dari penelitian yang dilakukan $90 \%$ anak sudah berkembang Kognitifnya, dikarenakan pihak sekolah sebagai fasilitator menstimulus anak anak dengan baik sehingga anak-anak tersebut kognitifnya sudah berkembang.

\section{DAFTAR PUSTAKA}

Ahmad Susanto, Perkembangan Anak Usia Dini Pengantar dalam Berbagai Aspeknya, (Jakarta:Kencana Prenadamedia Group, cetakan ke 3, 2014).

Ahmad susanto, perkembangan anak usia dini pengantar dalam berbagai aspeknya, Jakarta: Kencana, 2011.

Asrul, Strategi Pendidikan Anak Usia Dini,(Medan:Perdana Publishing, Cetakan pertama, 2016).

Asrul, Strategi Pendidikan Anak Usia Dini,(Medan:Perdana Publishing, Cetakan pertama, 2016).

Imam Bukhari, Kitab Shahih Buhari, Bab al-Jana'iz, bab ma qila aulad al-musyrikin, Juz. 5, h. 181, No. 1296.

Imas Kurniangsih,( 2016), Ragam Pengembangan Model Pembelajaran, Jakarta: Kata Pena. Khadijah, (2016), Pengembangan Kognitif Anak Usia Dini, Medan: Perdana Publishing.

Khadijah, Pengembangan Kognitif Anak Usia Dini Teori dan Pegembangannya, (Medan:Perdana Publishing, Cetakan kedua, 2017).

Lexy J. Moleong, Metodologi Penelitian Kualitatif, Bandung: PT. Remaja Rosdakarya, 2010

M. Quraissh Shihab, (2002), Tafsir Al-Qur'an, Jakarta: Lentera Hati.

Maisarah (2018). Matematika dan Sains Anak Usia Dini. Medan: Akasha Sakti.

Masganti, sitorus, (2015), Psikologi Perkembangan Anak Usia Dini, Medan: Perdana Publishing.

Menteri Pendidikan (2009). Peraturan Mendiknas No. 58 Tentang Standar Pendidikan Anak Usia Dini. Jakarta: Departemen Pendidikan Nasional.

Menteri Pendidikan dan Kebudayaan (2014). Peraturan menteri Pendidikan dan Kebudayaan Republik Indonesia Nomor 137 Tahun 2014 Tentang Standar nasional Pendidikan Anak Usia Dini, Jakarta: Menteri Pendidikan dan Kebudayaan RI. 
Menteri Pendidikan Nasional (2009). Peraturan Menteri Pendidikan Nasional Nomor 58 Tahun 2009 Tentang Standar Pendidikan Anak Usia Dini. Jakarta: Menteri Pendidikan Nasional.

Mohd. Surya. Psikologi Pembelajaran dan pengajaran. Bandung: Yayasan Bhakti Winajaya. 2003.

Muhammad Fadillah \& Lilif Mualifatu Khorida. Pendidikan Karakter Anak Usia Dini. Yogyakarta: Pustaka Hidayah. 2013

Nasution, Metode Research (penelitian ilmiah), Jakarta: Bumi Aksara, 2003.

Nur Ahmadi Bi Rahmani, Metodologi Penelitian Ekonomi, Medan: FEBI UIN-SU PRESS.

Nur Indriantoro dan Bambang Supomo, Metodologi Penelitian Bisnis Untuk Akutansi dan Manajemen, Yogyakarta: BPFE, 2002.

Nurul Zuriah, Metodologi Penelitian Sosial Dan Pendidikan, Jakarta: PT. Bumi Aksara, 2006.

Nurussakinah Daulay, Psikologi Pendidikan dan Permasalahan Umum Peserta Didik, (Medan:Perdana Publishing, cetakan pertama, 22019).

Ratna Wilis Dahar, Theories Belajar dan Pembelajaran, Jakarta: Erlangga, 2011.

Riyanto Yatim. Paradigma Pembelajaran. Jakarta: Prenada Media Group. 2009.

Rusydi Ananda (2016). inovasi Pendidikan, Medan:CV. Widya Puspita.

Sermal Pohan, (Editor: Asrul dan Ahmad Syukri Sitorus), (2016). Strategi Pendidikan Anak Usia Dini Dalam Membina Sumber Daya Manusia Berkarakter, Medan: Perdana Publishing.

Soenarjo, (2003), Al Qur'an dan Terjemah, Jakarta: Departemen Agama RI.

Sugiono, Metode Penelitian Kuantitatif Kualitatif dan R\&D, Bandung: Alfabeta, 2014

Sugiono, Metode Penelitian Pendidikan Pendekatan Kuantitatif, Kualitatif, dan R\&D, Bandung: Alfabeta

Wina Sanjaya. Strategi Pembelajaran Berorientasi Standar Proses Pendidikan. Jakarta: Prenada Media Group. 2010.

Wina Sanjaya. Strategi Pembelajaran Berorientasi Standar Proses Pendidikan. Yudrik Jahja. psikologi perkembangan. Jakarta: Prenada Media Group. 2011. 